\title{
Pengaruh Dosis dan Cara Pemberian Pupuk Anorganik terhadap Pertumbuhan Kakao ( Theobroma cacao L.) Belum Menghasilkan Klon Sulawesi 1
}

\author{
Ester M L Tobing ${ }^{*}$, Santi Rosniawaty ${ }^{2}$, and Moch Arief Soleh ${ }^{2}$ \\ ${ }^{1}$ Program Studi Agroteknologi, Fakultas Pertanian, Universitas Padjadjaran \\ Jl. Raya Bandung, Sumedang km.21, Jatinangor 45363, Jawa Barat, Indonesia \\ ${ }^{2}$ Departemen Budidaya Pertanian, Fakultas Pertanian, Universitas Padjadjaran \\ Jl. Raya Bandung, Sumedang km.21, Jatinangor 45363, Jawa Barat, Indonesia \\ *Email: esmitobing@gmail.com
}

\section{ABSTRACT \\ Effect of dosage and application method of inorganic fertilizer on the growth of immature cacao (Theobroma cacao L.) tree clone Sulawesi 1}

\begin{abstract}
Cacao tree is widely cultivated in Indonesia, especially in smallholder estate. The production of cacao in Indonesia is still below to its optimum potency. The production of cacao can be improved by adding inorganic fertilizer. The effectiveness of nutrient absorption by plant depends on several factors, including the right dosage and application method of fertilizer. This research aimed to get the best dosage and application method of inorganic fertilizer that give significant growth to immature cacao tree. This experiment was conducted at Ciparanje Experimental Station, Faculty of Agriculture, Padjadjaran University, from December 2018 to April 2019. This experiment was arranged in a Randomized Block Design with nine treatments and three replications. The treatments consisted of dosage and application method of inorganic fertilizer, the dosages were as follows: without fertilizer; single fertilizer with one level, i.e. $45 \mathrm{~g} / \mathrm{plant}$ of urea, $60 \mathrm{~g} / \mathrm{plant}$ of SP36, $35 \mathrm{~g} /$ plant of KCl; and NPKMg tablet compound fertilizer (20:10:10:2) with three levels, i.e. 30 g/plant, $60 \mathrm{~g} / \mathrm{plant}, 90 \mathrm{~g} / \mathrm{plant}$, while application methods were as follows: spreaded and poured. The result showed that dosage and application method of inorganic fertilizer significantly affect the growth of immature cacao especially to the variable of leaf area, leaf chlorophyll index, number of flush, and flush length. Application of $90 \mathrm{~g} / \mathrm{plant}$ NPKMg tablet compound fertilizer (20:10:10:2) by spreading could increase the growth of immature cacao.
\end{abstract}

Keywords: Immature cacao tree, Inorganic fertilizer, Dosage, Application method

\section{ABSTRAK}

Tanaman kakao banyak dibudidayakan di Indonesia, khususnya di perkebunan rakyat. Produksi kakao di Indonesia masih di bawah potensi hasil kakao secara umum. Peningkatan produksi perlu dilakukan, salah satunya dengan melakukan pemberian pupuk anorganik. Keefektifan penyerapan unsur hara oleh tanaman tergantung pada beberapa faktor, diantaranya dosis pupuk dan cara aplikasi pupuk yang tepat. Penelitian ini bertujuan untuk memperoleh dosis dan cara pemberian pupuk anorganik yang memberikan pengaruh terbaik pada pertumbuhan tanaman kakao belum menghasilkan. Percobaan dilaksanakan di Kebun Percobaan Ciparanje, Fakultas Pertanian, Universitas Padjadjaran, pada bulan Desember 2018 sampai bulan April 2019. Penelitian menggunakan rancangan acak kelompok (RAK) dengan sembilan perlakuan yang diulang sebanyak tiga kali. Perlakuan terdiri dari dosis dan cara pemberian pupuk anorganik, dengan dosis pupuk meliputi: tanpa pemupukan; pupuk tunggal dengan satu taraf, yaitu $45 \mathrm{~g} / \mathrm{tanaman}$ urea, 60 g/tanaman SP-36, $35 \mathrm{~g} /$ tanaman KCl; dan pupuk majemuk tablet NPKMg (20:10:10:2) dengan tiga taraf, yaitu $30 \mathrm{~g} /$ tanaman, $60 \mathrm{~g} /$ tanaman, $90 \mathrm{~g} / \operatorname{tanaman}$, sedangkan cara pemberian pupuk meliputi: disebar dan ditabur. Hasil penelitian menunjukkan bahwa dosis dan cara pemberian pupuk anorganik berpengaruh nyata terhadap pertumbuhan kakao belum menghasilkan terutama pada 
parameter luas daun, indeks klorofil daun, jumlah flush, dan panjang flush. Pemberian 90 g/tanaman pupuk majemuk tablet NPKMg (20:10:10:2) dengan cara ditabur mampu meningkatkan pertumbuhan kakao belum menghasilkan.

Kata Kunci: Kakao belum menghasilkan, Pupuk anorganik, Dosis, Cara pemberian

\section{PENDAHULUAN}

Kakao (Theobroma cacao L.) merupakan tanaman perkebunan yang berasal dari Amerika Selatan. Kakao banyak dibudidayakan di Indonesia, khususnya di perkebunan rakyat. Tanaman kakao dapat berbunga dan berbuah sepanjang tahun, sehingga dapat memenuhi kebutuhan ekspor dan menjadi sumber pendapatan negara. Biji kakao merupakan bahan utama dalam pembuatan makanan dan minuman.

Pada tahun 2016 Indonesia menjadi negara pengekspor biji kakao terbesar ketiga dunia dengan produksi biji kering 330.000 ton (ICCO, 2017). Permasalahan yang dihadapi saat ini adalah tingkat produktivitas biji kakao yang mengalami penurunan sehingga menyebabkan volume ekspor kakao mengalami penurunan. Pada umumnya tingkat produktivitas biji kakao kurang dari 1 ton/ha/tahun biji kering. Produktivitas ini masih di bawah potensi hasil kakao yang dapat mencapai 2 ton/ha/tahun biji kering (Direktorat Jenderal Perkebunan, 2010).

Peningkatan produktivitas kakao perlu dilakukan agar dapat memaksimalkan potensi hasil kakao. Peningkatan produktivitas kakao dapat dilakukan dengan melakukan pemeliharaan yang intensif terutama pada fase tanaman belum menghasilkan (TBM). Salah satu pemeliharaan yang perlu dilakukan adalah pemupukan. Pemupukan perlu dilakukan untuk mengganti kehilangan unsur hara dalam tanah akibat pencucian serta bertujuan untuk memenuhi kebutuhan unsur hara bagi tanaman sehingga dapat meningkatkan produktivitas tanaman (Susila dkk., 2010).

Unsur-unsur hara utama yang perlu ditambahkan pada pemupukan tanaman meliputi nitrogen, fosfor, kalium, dan magnesium (Tarigan, 2018). Pada umumnya unsur-unsur tersebut dapat diperoleh melalui penambahan pupuk anorganik pada tanah.

Pemberian pupuk anorganik pada tanaman dapat dilakukan dengan pupuk tunggal maupun pupuk majemuk (Rosmarkam \& Yuwono, 2002). Pupuk majemuk tablet adalah pupuk yang sering digunakan untuk meningkatkan efisiensi pemupukan (Hasibuan, 2010). Pemakaian pupuk majemuk tablet harus disesuaikan dengan umur tanaman sehingga diperlukan penelitian mengenai dosis yang tepat sesuai dengan umur tanaman kakao (Setiawan, 2006).

Tingkat keefektifan penyerapan unsur hara oleh tanaman tergantung pada beberapa faktor, diantaranya dosis pupuk dan cara aplikasi pupuk yang tepat (Dhalimi, 2006). Berdasarkan hal tersebut, perlu dilakukan penelitian mengenai pengaruh dosis dan cara pemberian pupuk anorganik terhadap pertumbuhan kakaobelum menghasilkan.

\section{BAHAN DAN METODE}

Penelitian dilaksanakan pada bulan Desember 2018-April 2019 di Kebun Percobaan Ciparanje Fakultas Pertanian Universitas Padjadjaran, Jatinangor, Kabupaten Sumedang, Jawa Barat dengan ketinggian $\pm 752 \mathrm{mdpl}$. Bahan yang digunakan adalah tanaman kakao klon Sulawesi 1berumur 21 bulan (TBM 1), pupuk anorganik tunggal (45 g/tanaman urea, $60 \mathrm{~g} /$ tanaman SP-36, dan $35 \mathrm{~g} /$ tanaman $\mathrm{KCl})$, pupuk majemuk tablet NPKMg (20:10:10:2), dan air.

Percobaan ini dilaksanakan menggunakan Rancangan Acak Kelompok (RAK) yang terdiri dari 9 perlakuan dan diulang sebanyak 3 kali dan masingmasing perlakuan terdiri dari 2 tanaman sehingga diperoleh 54 satuan percobaan. Perlakuan sebagai berikut:

A = Tanpa pemupukan

$\mathrm{B}=$ pupuk tunggal + ditabur

$\mathrm{C}=$ pupuk tunggal + disiram

$\mathrm{D}=30 \mathrm{~g} /$ tanaman majemuk tablet $\mathrm{NPKMg}+$ ditabur $\mathrm{E}=30 \mathrm{~g} /$ tanaman majemuk tablet $\mathrm{NPKMg}+$ disiram $\mathrm{F}=60 \mathrm{~g} /$ tanaman majemuk tablet NPKMg + ditabur $\mathrm{G}=60 \mathrm{~g} /$ tanaman majemuk tablet NPKMg + disiram $\mathrm{H}=90 \mathrm{~g} /$ tanaman majemuk tablet NPKMg + ditabur $\mathrm{I}=90 \mathrm{~g} /$ tanaman majemuk tablet $\mathrm{NPKMg}+$ disiram

\section{HASIL DAN PEMBAHASAN}

\section{Pertambahan Tinggi Tanaman (cm)}

Hasil pengamatan menunjukkan bahwa pengaruh dosis dan cara pemberian pupuk terhadap pertambahan tinggi tanaman kakao diperoleh seperti 
pada Tabel 1. Hasil uji $F$ pada analisis ragam menunjukkan bahwa dosis dan cara pemberian pupuk anorganik tidak berpengaruh nyata terhadap pertambahan tinggi tanaman kakao belum menghasilkan. Hal ini diduga disebabkan karena tanaman yang digunakan dalam penelitian telah membentuk jorquette (tempat percabangan dari pola percabangan ortrotop ke plagiotrop) sehingga relatif tidak ada lagi pertambahan tinggi tanaman. Pada umur tanaman kakao yang akan memasuki TBM tahun kedua, tanaman telah membentuk cabang primer (Wachjar \& Kadarisman, 2007).

Tabel 1. Rata-rata pertambahan tinggi tanaman kakao

\begin{tabular}{|c|c|c|c|c|c|c|c|c|}
\hline \multirow{3}{*}{ Perlakuan } & \multicolumn{8}{|c|}{ Pertambahan tinggi tanaman $(\mathrm{cm})$} \\
\hline & \multicolumn{8}{|c|}{ Minggu setelah perlakuan (MSP) } \\
\hline & 2 & 4 & 6 & 8 & 10 & 12 & 14 & 16 \\
\hline A & 0,39 & 0,47 & 0,60 & 0,60 & 0,32 & 0,32 & 0,31 & 0,30 \\
\hline B & 0,17 & 0,19 & 0,23 & 0,24 & 0,56 & 0,48 & 0,44 & 0,34 \\
\hline $\mathrm{C}$ & 0,32 & 0,46 & 0,51 & 0,58 & 0,25 & 0,19 & 0,17 & 0,16 \\
\hline $\mathrm{D}$ & 0,06 & 0,13 & 0,15 & 0,16 & 0,58 & 0,39 & 0,36 & 0,34 \\
\hline $\mathrm{E}$ & 0,28 & 0,33 & 0,35 & 0,40 & 0,37 & 0,34 & 0,30 & 0,30 \\
\hline $\mathrm{F}$ & 0,18 & 0,26 & 0,31 & 0,34 & 0,46 & 0,41 & 0,38 & 0,37 \\
\hline G & 0,55 & 0,57 & 0,66 & 0,68 & 0,22 & 0,19 & 0,18 & 0,16 \\
\hline $\mathrm{H}$ & 0,35 & 0,41 & 0,46 & 0,46 & 0,37 & 0,33 & 0,29 & 0,23 \\
\hline I & 0,03 & 0,18 & 0,27 & 0,27 & 0,51 & 0,51 & 0,45 & 0,41 \\
\hline
\end{tabular}

Keterangan: Angka yang tidak memiliki huruf menunjukkan tidak terdapat pengaruh nyata menurut hasil uji $\mathrm{F}$ pada analisis ragam. $\mathrm{A}=$ Tanpa pemupukan, $\mathrm{B}=$ pupuk tunggal + ditabur, $\mathrm{C}=$ pupuk tunggal + disiram, $\mathrm{D}=30 \mathrm{~g} / \mathrm{tanaman}$ majemuk tablet $\mathrm{NPKMg}+$ ditabur, $\mathrm{E}=30 \mathrm{~g} /$ tanaman majemuk tablet NPKMg + disiram, $\mathrm{F}=60 \mathrm{~g} /$ tanaman majemuk tablet NPKMg + ditabur, $\mathrm{G}=60$ $\mathrm{g} /$ tanaman majemuk tablet NPKMg + disiram, $\mathrm{H}=90 \mathrm{~g} /$ tanaman majemuk tablet NPKMg + ditabur, $\mathrm{I}=90 \mathrm{~g} / \operatorname{tanaman}$ majemuk tablet NPKMg + disiram.

\section{Pertambahan Luas Daun $\left(\mathrm{cm}^{2}\right)$}

Hasil uji $F$ pada Analisis Ragam menunjukkan bahwa dosis dan cara pemberian pupuk anorganik berpengaruh nyata terhadap pertambahan luas daun tanaman kakao belum menghasilkan. Rata-rata pertambahan luas daun setelah dilakukan uji lanjut Duncan pada taraf 5\% dapat dilihat pada Tabel 2.

Tabel 2. Rata-rata pertambahan luas daun kakao

\begin{tabular}{|c|c|c|c|c|c|c|c|c|}
\hline \multirow{3}{*}{ Perlakuan } & \multicolumn{8}{|c|}{ Pertambahan luas daun $\left(\mathrm{cm}^{2}\right)$} \\
\hline & \multicolumn{8}{|c|}{ Minggu setelah perlakuan (MSP) } \\
\hline & 2 & 4 & 6 & 8 & 10 & 12 & 14 & 16 \\
\hline A & $5,21 \mathrm{c}$ & $7,29 \mathrm{~b}$ & $13,01 \mathrm{c}$ & 23,16 & 45,98 & 79,32 & 83,65 & 89,75 \\
\hline $\mathrm{B}$ & $10,81 \mathrm{bc}$ & $16,38 \mathrm{a}$ & 21,94 bc & 33,63 & 46,58 & 77,66 & 82,85 & 94,66 \\
\hline $\mathrm{C}$ & $12,72 \mathrm{abc}$ & 20,10 a & $27,87 \mathrm{ab}$ & 42,14 & 59,82 & 73,35 & 106,01 & 119,73 \\
\hline $\mathrm{D}$ & 11,24 bc & $15,91 \mathrm{a}$ & $21,10 \mathrm{bc}$ & 30,90 & 50,60 & 65,47 & 113,94 & 126,18 \\
\hline $\mathrm{E}$ & $18,71 \mathrm{ab}$ & 21,06 a & $28,53 \mathrm{ab}$ & 38,27 & 59,06 & 67,78 & 75,19 & 94,90 \\
\hline $\mathrm{F}$ & $18,18 \mathrm{ab}$ & $24,34 \mathrm{a}$ & 29,36 b & 36,03 & 52,64 & 62,13 & 83,66 & 102,84 \\
\hline G & 19,65 a & 23,79 a & $26,91 \mathrm{ab}$ & 33,20 & 48,31 & 77,50 & 90,77 & 111,42 \\
\hline $\mathrm{H}$ & $18,86 \mathrm{ab}$ & 24,97 a & $34,04 \mathrm{a}$ & 44,61 & 54,04 & 65,69 & 67,80 & 87,65 \\
\hline I & $13,28 \mathrm{ab}$ & $19,31 \mathrm{a}$ & $29,57 \mathrm{ab}$ & 36,50 & 48,35 & 56,36 & 66,05 & 80,34 \\
\hline \multicolumn{9}{|c|}{$\begin{array}{l}\text { Keterangan: } \\
\text { 1. Angka yang tidak memiliki huruf menunjukkan tidak terdapat pengaruh nyata menurut hasil uji } \mathrm{F} \text { pada analisis ragam. } \\
\text { 2. Angka yang diikuti dengan huruf yang sama menunjukkan tidak berbeda nyata menurut uji lanjut Duncan pada taraf } 5 \% \text {. } \\
\text { 3. } \mathrm{A}=\text { Tanpa pemupukan, } \mathrm{B}=\text { pupuk tunggal }+ \text { ditabur, } \mathrm{C}=\text { pupuk tunggal }+ \text { disiram, } \mathrm{D}=30 \mathrm{~g} / \text { tanaman majemuk tablet } \mathrm{NPKMg}+ \\
\text { ditabur, } \mathrm{E}=30 \mathrm{~g} / \text { tanaman majemuk tablet } \mathrm{NPKMg}+\text { disiram, } \mathrm{F}=60 \mathrm{~g} / \mathrm{tanaman} \text { majemuk tablet } \mathrm{NPKMg}+\text { ditabur, } \mathrm{G}=60 \mathrm{~g} / \mathrm{tanaman} \\
\text { majemuk tablet } \mathrm{NPKMg}+\text { disiram, } \mathrm{H}=90 \mathrm{~g} / \text { tanaman majemuk tablet } \mathrm{NPKMg}+\text { ditabur, } \mathrm{I}=90 \mathrm{~g} / \text { tanaman majemuk tablet } \mathrm{NPKMg}+ \\
\text { disiram. }\end{array}$} \\
\hline
\end{tabular}


Pada 2 MSP perlakuan G (60 g/tanaman majemuk tablet + disiram) memberikan pengaruh terbaik terhadap parameter pertambahan luas daun. Pada 4 MSP semua perlakuan memberikan pengaruh terbaik terhadap parameter pertambahan luas daun apabila dibandingkan dengan perlakuan A (tanpa pemupukan). Pada 6 MSP perlakuan H (90 $\mathrm{g} /$ tanaman majemuk tablet + ditabur) memberikan pengaruh terbaik terhadap parameter pertambahan luas daun.

Hal ini menunjukkan bahwa perlakuan pemberian pupuk mampu membantu meningkatkan pertumbuhan tanaman apabila dibandingkan dengan tanpa pemberian pupuk. Syarif (1985) dalam Thuti dkk. (2017) menyatakan bahwa unsur P digunakan dalam perkembangan jaringan meristem. Berkembangnya jaringan meristem menyebabkan sel-sel akan memanjang dan membesar, sehingga bagian tanaman seperti daun dan pucuk akan semakin panjang dan lebar serta akan mempengaruhi luas daun tanaman.
Pertambahan luas daun hanya berpengaruh pada awal pengamatan diduga disebabkan karena secara fisiologis, daun merupakan organ tanaman yang memiliki pertumbuhan terbatas. Luas daun meningkat berangsur-angsur hingga mencapai batas pertumbuhan maksimum (Suryati, 2015). Penambahan unsur hara akan memacu pertambahan luas daun, namun semakin mendekati ukuran maksimum, pengaruh pertambahan unsur hara terhadap pertambahan luas daun akan semakin kecil (Gardner dkk., 1991).

\section{Indeks Klorofil Daun}

Hasil uji $F$ pada analisis ragam menunjukkan bahwa dosis dan cara pemberian pupuk anorganik berpengaruh nyata terhadap pertambahan luas daun tanaman kakao belum menghasilkan. Rata-rata indeks klorofil setelah dilakukan uji lanjut Duncan pada taraf 5\% dapat dilihat pada Tabel 3 .

Tabel 3. Rata-rata indeks klorofil daun kakao

\begin{tabular}{cccccccc}
\hline & \multicolumn{7}{c}{ Minggu setelah perlakuan (MSP) } \\
\cline { 2 - 8 } Perlakuan & 1 & 2 & 3 & 4 & 8 & 12 & 16 \\
\cline { 2 - 8 } & 34,40 & 37,59 & 38,07 & $43,61 \mathrm{abcd}$ & 45,51 & 48,18 & $45,91 \mathrm{ab}$ \\
A & 31,16 & 36,26 & 39,87 & $43,96 \mathrm{abcd}$ & 41,99 & 46,51 & $45,78 \mathrm{ab}$ \\
B & 33,51 & 38,27 & 41,28 & $44,61 \mathrm{abc}$ & 45,04 & 45,48 & $44,18 \mathrm{abc}$ \\
C & 37,47 & 40,15 & 39,01 & $37,73 \mathrm{bcd}$ & 38,36 & 42,49 & $39,35 \mathrm{bcd}$ \\
D & 37,02 & 40,73 & 43,91 & $47,18 \mathrm{a}$ & 43,11 & 48,37 & $44,47 \mathrm{abc}$ \\
E & 34,68 & 39,88 & 42,66 & $46,73 \mathrm{ab}$ & 42,95 & 46,32 & $43,41 \mathrm{abc}$ \\
F & 31,18 & 34,31 & 33,13 & $35,35 \mathrm{~d}$ & 36,65 & 36,98 & $32,75 \mathrm{~d}$ \\
G & 35,16 & 36,08 & 38,97 & $42,65 \mathrm{abcd}$ & 39,66 & 46,42 & $49,72 \mathrm{a}$ \\
H & 29,58 & 35,28 & 37,31 & $36,19 \mathrm{~cd}$ & 37,29 & 40,43 & $37,06 \mathrm{~cd}$ \\
I & & & & & & &
\end{tabular}

Keterangan:

1. Angka yang tidak memiliki huruf menunjukkan tidak terdapat pengaruh nyata menurut hasil uji $\mathrm{F}$ pada analisis ragam.

2. Angka yang diikuti dengan huruf yang sama menunjukkan tidak berbeda nyata menurut uji lanjut Duncan pada taraf $5 \%$.

3. $\mathrm{A}=$ Tanpa pemupukan, $\mathrm{B}=$ pupuk tunggal + ditabur, $\mathrm{C}=$ pupuk tunggal + disiram, $\mathrm{D}=30 \mathrm{~g} /$ tanaman majemuk tablet $\mathrm{NPKMg}+$ ditabur, $\mathrm{E}=30 \mathrm{~g} / \mathrm{tanaman}$ majemuk tablet NPKMg + disiram, $\mathrm{F}=60 \mathrm{~g} / \operatorname{tanaman}$ majemuk tablet NPKMg + ditabur, $\mathrm{G}=60 \mathrm{~g} / \operatorname{tanaman}$ majemuk tablet NPKMg + disiram, $\mathrm{H}=90 \mathrm{~g} /$ tanaman majemuk tablet NPKMg + ditabur, I = $90 \mathrm{~g} /$ tanaman majemuk tablet $\mathrm{NPKMg}+$ disiram.

Pada umur 1 MSP sampai 3 MSP, dosis dan cara pemberian pupuk belum memberikan perbedaan yang signifikan antar perlakuan diduga disebabkan karena pada umur tersebut, tanaman belum mampu menyerap unsur hara yang tersedia di tanah, sehingga belum dapat dimanfaatkan untuk pembentukan klorofil daun. Pada umur 4 MSP perlakuan E (30 g/tanaman majemuk tablet NPKMg (20:10:10:2) dengan cara disiram) memberikan pengaruh terbaik terhadap parameter indeks klorofil daun. Berdasarkan hal tersebut dapat dikatakan bahwa pemberian dosis $30 \mathrm{~g} /$ tanaman pupuk majemuk tablet NPKMg dengan cara dicairkan terlebih dahulu mampu diserap cepat oleh tanaman. 
Hal ini sejalan dengan pernyataan Akil (2009) bahwa pelarutan pupuk dalam air sebelum disiram di sekitar tanaman cukup efektif karena penyerapan pupuk oleh tanaman akan lebih cepat. Pemberian pupuk dengan cara disiram akan mempermudah tanaman untuk menyerap unsur hara yang dibutuhkan oleh tanaman khususnya unsur N, P dan $\mathrm{K}$ yang berasal dari pupuk majemuk tablet.

Pada 8 MSP sampai 14 MSP perlakuan E (30 $\mathrm{g} /$ tanaman majemuk tablet NPKMg (20:10:10:2) dengan cara disiram) tidak memberikan pengaruh terbaik terhadap indeks klorofil daun diduga disebabkan karena unsur hara yang diberikan sudah tidak tersedia lagi bagi tanaman. Hal ini sejalan dengan pernyataan Triyono dkk. (2013) bahwa pemberian pupuk dengan cara dicairkan menyebabkan kemungkinan hilangnya unsur hara semakin tinggi akibat proses leaching sehingga tidak tersedia dalam waktu yang lama.

Pada umur 16 MSP perlakuan $90 \mathrm{~g} /$ tanaman majemuk tablet NPKMg (20:10:10:2) dengan cara ditabur $(\mathrm{H})$ memberikan pengaruh terbaik terhadap parameter indeks klorofil daun. Menurut Wijaya dkk. (2014) pupuk majemuk tablet yang mengandung $\mathrm{N}, \mathrm{P}, \mathrm{K}$, dan $\mathrm{Mg}$ memiliki sifat lambat dalam melepaskan unsur hara (slow release) untuk 3 bulan hingga 12 bulan. Hal ini menyebabkan perlakuan $90 \mathrm{~g} /$ tanaman majemuk tablet $\mathrm{NPKMg}$ (20:10:10:2) dengan cara ditabur baru memberikan pengaruh nyata terhadap indeks klorofil daun pada umur 16 MSP.

Klorofil merupakan pigmen pemberi warna hijau pada tanaman. Pigmen ini berperan dalam proses fotosintesis dengan menyerap dan mengubah energi cahaya menjadi energi kimia (Dwidjoseputro, 1994). Berdasarkan pernyataan Marvelia dkk. (2006) bahwa unsur hara $\mathrm{N}$ berperan dalam pembentukan klorofil pada daun sehingga daun berkemampuan untuk menyerap cahaya matahari dalam membantu proses fotosintesis. Klorofil dapat terbentuk dengan memanfaatkan unsur hara $\mathrm{N}$ dan $\mathrm{Mg}$ yang tersedia bagi tanaman (Wardiana \& Mahmud, 2003). Menurut Lakitan (1996) dalam Syahputra dan Wardati (2015), unsur hara $\mathrm{K}$ berfungsi sebagai penyusun klorofil dan sebagai aktivator berbagai enzim dalam reaksi fotosintesis dan respirasi.

\section{Jumlah Flush}

Hasil uji $F$ pada analisis ragam menunjukkan bahwa dosis dan cara pemberian pupuk anorganik berpengaruh nyata terhadap jumlah flush tanaman kakao belum menghasilkan. Rata-rata indeks klorofil setelah dilakukan uji lanjut Duncan pada taraf 5\% dapat dilihat pada Tabel 4.

Tabel 4. Rata-rata Jumlah Flush Kakao

\begin{tabular}{cccccccc}
\hline & \multicolumn{7}{c}{ Jumlah Flush } \\
\cline { 2 - 7 } Perlakuan & \multicolumn{7}{c}{ Minggu Setelah Perlakuan (MSP) } \\
\cline { 2 - 8 } & 1 & 2 & 3 & 4 & 8 & 12 & 16 \\
\hline A & 8,67 & 7,33 & 11,00 & 12,33 & 1,25 & 8,83 & $0,75 \mathrm{c}$ \\
B & 5,50 & 12,83 & 16,17 & 19,33 & 8,17 & 9,17 & $4,50 \mathrm{bc}$ \\
C & 9,83 & 13,17 & 17,00 & 19,17 & 7,83 & 13,50 & $11,75 \mathrm{ab}$ \\
D & 8,75 & 11,17 & 11,50 & 11,50 & 7,75 & 3,33 & $12,67 \mathrm{ab}$ \\
E & 2,17 & 6,83 & 7,00 & 8,17 & 7,83 & 11,00 & $0,75 \mathrm{c}$ \\
F & 5,50 & 14,50 & 20,50 & 20,67 & 4,75 & 4,83 & $11,83 \mathrm{ab}$ \\
G & 3,33 & 3,00 & 3,67 & 5,33 & 1,50 & 0,00 & $2,50 \mathrm{bc}$ \\
H & 8,17 & 5,00 & 5,00 & 4,83 & 12,17 & 3,83 & $15,17 \mathrm{a}$ \\
I & 3,33 & 4,67 & 5,50 & 8,50 & 6,75 & 0,50 & $2,25 \mathrm{bc}$ \\
\hline
\end{tabular}

Keterangan:

1. Angka yang tidak memiliki huruf menunjukkan tidak terdapat pengaruh nyata menurut hasil uji $\mathrm{F}$ pada analisis ragam.

2. Angka yang diikuti dengan huruf yang sama menunjukkan tidak berbeda nyata menurut uji lanjut Duncan pada taraf $5 \%$.

3. Tanpa pemupukan, $\mathrm{B}=$ pupuk tunggal + ditabur, $\mathrm{C}=$ pupuk tunggal + disiram, $\mathrm{D}=30 \mathrm{~g} /$ tanaman majemuk tablet $\mathrm{NPKMg}+\operatorname{ditabur}, \mathrm{E}$ $=30 \mathrm{~g} /$ tanaman majemuk tablet NPKMg + disiram, $\mathrm{F}=60 \mathrm{~g} /$ tanaman majemuk tablet NPKMg + ditabur, $\mathrm{G}=60 \mathrm{~g} / \mathrm{tanaman}$ majemuk tablet NPKMg + disiram, $\mathrm{H}=90 \mathrm{~g} /$ tanaman majemuk tablet NPKMg + ditabur, I = $90 \mathrm{~g} /$ tanaman majemuk tablet $\mathrm{NPKMg}+$ disiram.

Flush merupakan daun muda yang baru terbentuk sementara flushing adalah proses keluarnya daun-daun muda. Flushing bergantung pada faktor iklim, unsur hara tersedia, sifat fisik tanah dan kandungan kimia, edafik dan biotik 
yang kemudian mempengaruhi proses fisiologis internal (Kozlowski, 1971).

Pada umur 16 MSP perlakuan H (90 $\mathrm{g} /$ tanaman majemuk tablet + ditabur) mampu memberikan hasil terbaik pada parameter jumlah flush tanaman kakao belum menghasilkan. Hal ini sejalan dengan pernyataan Lakitan (1996) dalam Marajahan dkk. (2012) unsur hara yang paling berpengaruh terhadap pertumbuhan dan perkembangan daun adalah N. Kandungan N yang terdapat dalam tanah akan dimanfaatkan oleh tanaman kakao dalam pembelahan sel. Pembelahan oleh pembesaran sel-sel yang muda akan membentuk primordia daun.

\section{Panjang Flush}

Hasil uji F pada analisis ragam menunjukkan bahwa dosis dan cara pemberian pupuk anorganik berpengaruh nyata terhadap jumlah flush tanaman kakao belum menghasilkan. Rata-rata indeks klorofil setelah dilakukan uji lanjut Duncan pada taraf 5\% dapat dilihat pada Tabel 5.

Tabel 5. Rata-rata panjang flush kakao

\begin{tabular}{cccccccc}
\hline & \multicolumn{7}{c}{ Panjang Flush $(\mathrm{cm})$} \\
\cline { 2 - 8 } Perlakuan & \multicolumn{7}{c}{ Minggu Setelah Perlakuan (MSP) } \\
\cline { 2 - 8 } & 1 & 2 & 3 & 4 & 8 & 12 & 16 \\
\hline A & 5,34 & 5,61 & 9,59 & 6,36 & 1,00 & 8,17 & $2,33 \mathrm{bc}$ \\
B & 4,06 & 1,08 & 3,41 & 9,13 & 8,56 & 8,31 & $2,53 \mathrm{bc}$ \\
C & 4,84 & 2,35 & 7,19 & 10,57 & 5,16 & 9,81 & $3,53 \mathrm{bc}$ \\
D & 5,60 & 6,84 & 4,98 & 7,93 & 5,29 & 5,44 & $8,11 \mathrm{ab}$ \\
E & 2,82 & 4,65 & 2,52 & 7,33 & 2,60 & 4,30 & $0,30 \mathrm{c}$ \\
F & 0,96 & 1,24 & 3,89 & 12,04 & 7,33 & 1,95 & $7,67 \mathrm{ab}$ \\
G & 7,13 & 9,53 & 4,67 & 4,62 & 0,81 & 0,00 & $1,31 \mathrm{bc}$ \\
H & 6,41 & 4,80 & 6,16 & 7,92 & 6,88 & 8,42 & $10,69 \mathrm{a}$ \\
I & 1,66 & 0,99 & 2,58 & 5,92 & 6,75 & 2,52 & $3,38 \mathrm{bc}$ \\
\hline
\end{tabular}

Keterangan:

1. Angka yang tidak memiliki huruf menunjukkan tidak terdapat pengaruh nyata menurut hasil uji $\mathrm{F}$ pada analisis ragam.

2. Angka yang diikuti dengan huruf yang sama menunjukkan tidak berbeda nyata menurut uji lanjut Duncan pada taraf $5 \%$.

3. Tanpa pemupukan, $\mathrm{B}=$ pupuk tunggal + ditabur, $\mathrm{C}=$ pupuk tunggal + disiram, $\mathrm{D}=30 \mathrm{~g} / \mathrm{tanaman}$ majemuk tablet $\mathrm{NPKMg}+$ ditabur, $\mathrm{E}$ $=30 \mathrm{~g} /$ tanaman majemuk tablet NPKMg + disiram, F = $60 \mathrm{~g} /$ tanaman majemuk tablet NPKMg + ditabur, $\mathrm{G}=60 \mathrm{~g} / \mathrm{tanaman}$ majemuk tablet NPKMg + disiram, $\mathrm{H}=90 \mathrm{~g} /$ tanaman majemuk tablet NPKMg + ditabur, $\mathrm{I}=90 \mathrm{~g} / \mathrm{tanaman}$ majemuk tablet NPKMg + disiram .

Pada umur 16 MSP perlakuan H (90 $\mathrm{g} /$ tanaman majemuk tablet + ditabur) mampu meningkatkan panjang flush tanaman kakao belum menghasilkan. Hal ini sejalan dengan pernyataan Wardani dkk. (2011) bahwa pembentukan pucuk dan daun-daun baru (flush) berkaitan dengan ketersediaan unsur hara bagi tanaman sehingga didapatkan bahan dan energi untuk proses pembelahan dan diferensiasi sel yang mengarah kepada proses morfogenesis jaringan seperti pembentukan daun.

Pemberian 90 g/tanaman pupuk majemuk tablet NPKMg dengan cara ditabur memberikan hasil yang lebih baik jika dibandingkan dengan pemberian pupuk dengan dosis yang sama namun dengan cara disiram. Hal ini menunjukkan bahwa pemberian pupuk dengan cara disiram lebih mudah larut sehingga tidak tersedia bagi tanaman dalam waktu yang lama sedangkan pemberian pupuk dengan cara ditabur dapat menyediakan hara bagi tanaman dalam waktu yang relatif lama. Pemberian pupuk dengan cara disiram pada tanaman mengakibatkan akurasi dan penyerapan pupuk oleh akar dapat lebih tinggi namun beresiko mengalami kehilangan (Novizan, 2002).

\section{SIMPULAN}

Berdasarkan hasil penelitian dan pembahasan diatas, maka dapat diambil kesimpulan sebagai berikut:

1. Terdapat dosis dan cara pemberian pupuk anorganik yang memberikan pengaruh baik terhadap pertumbuhan tanaman kakao belum menghasilkan klon Sulawesi 1 khususnya pada pertambahan luas daun, indeks klorofil daun, jumlah flush, dan panjang flush. 
2. Pemberian $90 \mathrm{~g} /$ tanaman majemuk tablet NPKMg (20:10:10:2) dengan cara ditabur mampu memberikan pengaruh terbaik terhadap peningkatan pertumbuhan tanaman kakao belum menghasilkan klon Sulawesi 1.

\section{DAFTAR PUSTAKA}

Akil, M. 2009. Aplikasi pupuk urea pada tanaman jagung. Balai Penelitian Tanaman Serealia. Prosiding Seminar Nasional Serealia 2009.

Dhalimi, A. 2006. Pengaruh dosis dan cara peletakan pupuk terhadap pertumbuhan tanaman kayu manis (Cinnamomum burmanii ROBX). Jurnal Littri. 12 (3): 98-102.

Direktorat Jenderal Perkebunan. 2010. Statistik Perkebunan Indonesia Komoditas Kakao. Departemen Pertanian. Jakarta. Tersedia online ditjenbun.pertanian.go.id. Diakses 17 Januari 2018.

Dwidjoseputro, D. 1994. Pigmen Klorofil. Erlangga. Jakarta

Gardner, PF, BR Pearee, and LR Mitchell. 1991. Fisiologi Tanaman Budidaya. UI Press. Jakarta.

Hasibuan, BE. 2010. Pupuk dan Pemupukan. USU Press. Medan.

ICCO. 2017. Quarterly Bulletin of Cocoa Statistics. Tersedia online pada www.icco.org. Diakses 9 Mei 2019.

Marajahan, Y, Islan, dan MA Khoiri. 2012. Aplikasi pupuk NPK terhadap pertumbuhan kakao (Theobroma cacao L.) yang ditanam diantara kelapa sawit. Jurnal Penelitan Agronomi. (1): 56-74.

Marvelia, A, S Darmanti, dan S Parman. 2006. Produksi tanaman jagung manis (Zea mays L. saccharata) yang diberlakukan dengan kompos kascing dengan dosis yang berbeda. Bul. Anatomi Fisiologi. 9 (1): 7-18.

Novizan. 2002. Petunjuk Pemupukan yang Efektif. Agromedia Pustaka. Jakarta.

Rosmarkam, A, dan NW Yuwono. 2002. Ilmu Kesuburan Tanah. Yogyakarta. Kanisius.

Setiawan, RA. 2006. Keefektifan pupuk majemuk lepas terkendali Pasir Maung Fertilizer (PMF) pada bibit kelapa sawit (Elaeis guineensis Jacq.) pada tanah Ultisol dari Jasinga. Institut Pertanian Bogor. Bogor.

Suryati, D, Sampurno, dan E Anom. 2015. Uji beberapa konsentrasi pupuk cair Azolla (Azolla pinnata) pada pertumbuhan bibit kelapa sawit (Elaeis guineensis Jacq.) di pembibitan utama. Jom Faperta. 2 (1): 1-13.

Susila, AD, JG Kartika, T Prasetyo, dan MC Palada. 2010. Fertilizer recommendation: correlation and calibration study of soil $\mathrm{P}$ test for yard long bean (Vigna unguilata L.) on Ultisols in Nanggung-Bogor. Jurnal Agron Indonesia. 38 (3): 225-231.

Syahputra, MA, dan Wardati. 2015. Pemberian pupuk majemuk NPK dan pupuk $\mathrm{Cu}$ untuk pertumbuhan tanaman kelapa sawit (Elaeis guineensis Jacq.) belum menghasilkan di lahan gambut. Jom Faperta. 2 (1): 1-11.

Tarigan, EW. 2018. Penentuan kadar nitrogen (N), fosfor $\left(\mathrm{P}_{2} \mathrm{O}_{5}\right)$, dan kalium $\left(\mathrm{K}_{2} \mathrm{O}\right)$ pada limbah kopi sebagai pupuk organik. Tersedia online pada repositori.usu.ac.id. Diakses 24 Juni 2018.

Thuti., AI Amri, dan Islan. 2017. Pengaruh pemberian beberapa jenis pupuk majemuk pada berbagai jenis tanah terhadap pertumbuhan bibit kelapa sawit (Elaeis guineensis Jacq.) di pre-nursery. Jom Faperta. 4 (1): 1-13.

Kozlowski, TT. 1971. Growth and Development of Trees: Seed Germination, Ontogeny, and Shoot Growth. Academic Press. New York.

Triyono, A, Purwanto, dan Budiyono. 2013. Efisiensi penggunaan pupuk $\mathrm{N}$ untuk pengurangan kehilangan nitrat pada lahan pertanian. Prosiding Seminar Nasional Pengelolaan Sumber Daya Alam dan Lingkungan 2013. Semarang.

Wachjar, A, dan L Kadarisman. 2007. Pengaruh kombinasi pupuk organik cair dan pupuk anorganik serta frekuensi aplikasinya terhadap pertumbuhan tanaman kakao (Theobroma cacao L.) belum menghasilkan. Jurnal Bul. Agron. 35 (3): 212-216.

Wardani, S, H Setiado, dan S Ilyas. 2011. Pengaruh media tanam dan pupuk daun terhadap aklimatisasi anggrek Dendrobium (Dendrobium sp). Jurnal Ilmu Pertanian KULTIVAR. 5(1): 11-18.

Wardiana, E, dan Z Mahmud. 2003. Tanaman sela diantara pertanaman kelapa sawit. Lokakarya Sistem Integrasi Kelapa SawitSapi. Hlm. 175-187. 